\title{
PENGARUH LEVERAGE DAN PROFITABILITAS TERHADAP KEBIJAKAN DIVIDEN PADA PERUSAHAAN PERTAMBANGAN BATUBARA YANG TERDAFTAR DI BURSA EFEK INDONESIA
}

\author{
Oleh: \\ Letty Meldawita Turnip \\ S1 Akuntansi \\ Darwin Lie, Parman Tarigan, Ady Inrawan
}

Abstrak

Tujuan dari penelitian ini adalah : 1) Untuk mengetahui gambaran Leverage, Profitabilitas dan Kebijakan Dividen. 2) Untuk mengetahui pengaruh Leverage dan Profitabilitas terhadap Kebijakan Dividen pada Perusahaan Pertambangan Batubara yang Terdaftar di Bursa Efek Indonesia Periode 2013-2015 baik secara simultan maupun parsial. Teknik analisis data yang dipergunakan dalam penelitian ini adalah analisis deskriptif kualitatif dan analisis deskriptif kuantitatif yang meliputi uji asumsi klasik, analisis regresi linier berganda, dan uji hipotesis.

Hasil penelitian dapat disimpulkan sebagai beriku: 1) Rata-rata leverage, profitabilitas dan kebijakan dividen masing-masing sebesar 0,84 0,19, dan 0,43. 2) Hasil regresi linier berganda, yaitu $\hat{\mathbf{Y}}$

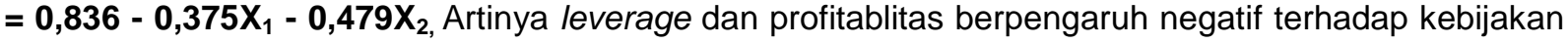
dividen pada Perusahaan Pertambangan Batubara yang Terdaftar di Bursa Efek Indonesia Periode 2013-2015. 3) Hasil uji koefisien korelasi (r) sebesar 0,621 yang artinya bahwa terdapat hubungan yang kuat antara leverage dan profitabilitas terhadap kebijakan dividen. 4) Hasil analisis Koefisien Determinasi ( $R$ square) adalah 0,386 atau $38,6 \%$, artinya leverage dan profitabilitas mampu menjelaskan /memberikan kontribusi sebesar 38,6\% terhadap kebijakan dividen. 5) Hasil penelitian menunjukkan bahwa leverage dan profitabilitas berpengaruh tidak signifikan terhadap kebijakan dividen pada Perusahaan Pertambangan Batubara yang Terdaftar di Bursa Efek Indonesia Periode 2013-2015. Sedangkan leverage berpengaruh signifikan terhadap kebijakan dividen sementara profitabilitas berpengaruh tidak signifikan terhadap kebijakan dividen pada Perusahaan Pertambangan Batubara yang Terdaftar di Bursa Efek Indonesia Periode 2013-2015.

Kata kunci: Leverage, Profitabilitas dan Kebijakan Dividen

\section{Abstract}

The purpose of this research are: 1). To determine the discripition of Leverage, Profitability and Dividend Policy. 2) To determine the influence of Leverage and Profitability on Dividend Policy at Coal Mining Company Listed in Indonesia Stock Exchange for the period 2013-2015 either simultaneosly or partialy. This research was done by using descriptive analysis method qualitative and quantitative descriptive analysis covering the classic assumption test, multiple linear regression, and hypothesis testing.

The result of this research concluded: 1) The average of Leverage Profitability and Dividend

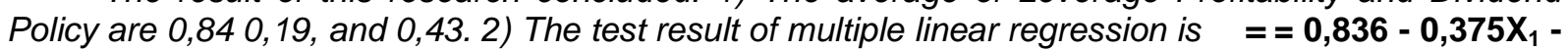
$\mathbf{0}, \mathbf{4 7 9} \mathrm{X}_{2}$, means that Leverage and Profitability have a negative effect on Dividend Policy at Coal Mining Company Listed in Indonesia Stock Exchange for the period 2013-2015. The result of the coefficient correlation $(r)$ is 0,621 , which means that there is a strong relationship between leverage and profitability on dividend policy. 4) The result of coefficient determination analysis is 0,386 or $38,6 \%$ which means that $38,6 \%$ variabel in the company value is explained by the Leverage and Profitability. 5) The study shows that Leverage and Profitability have no significant impact on Dividend Policy at Coal Mining Company Listed in Indonesia Stock Exchange for the period 2013-2015. Leverage has significant influence on Dividend Policy of the company while Profitability has no significant on Dividend Policy at Coal Mining Company Listed in Indonesia Stock Exchange for the period 2013-2015.

Keywords: Leverage, Profitability and Dividend Policy

\section{A. PENDAHULUAN}

\section{Latar Belakang Masalah}

Kebijakan dividen merupakan bagian yang tidak dapat dipisahkan dengan keputusan pendanaan perusahaan. Secara definisi kebijakan dividen adalah kebijakan untuk menentukan berapa laba yang harus dibayarkan (dividen) kepada pemegang saham dan berapa banyak yang harus ditanam kembali (laba ditahan). Besar kecilnya dividen yang akan diterima tergantung pada kebijakan masing-masing perusahaan, sehingga pertimbangan manajemen sangat diperlukan. Dengan demikian perlu bagi pihak manajemen untuk mempertimbangkan faktor-faktor apa saja yang akan mempengaruhi kebijakan dividen 
pada setiap perusahaan seperti leverage dan profitabilitas.

Apabila perusahaan menetapkan bahwa pelunasan utangnya akan diambilkan dari laba ditahan, berarti perusahaan harus menahan sebagian besar pendapatannya untuk keperluan tersebut, yang berarti bahwa hanya sebagian kecil saja dari pendapatan atau earning yang dapat dibayarkan sebagai dividen. Dengan kata lain perusahaan harus menetapkan dividend payout ratio yang rendah. Berdasarkan pernyataan tersebut, semakin tinggi debt to equity ratio maka dividen yang akan dibagikan kepada pemegang saham pun rendah.

Besar kecilnya dividen juga sangat tergantung oleh besar kecilnya laba yang diperoleh dan proporsi laba yang akan dibagikan dalam bentuk dividen atau dividend payout ratio. Sehingga perusahaan yang cenderung menghasilkan laba yang tinggi maka cenderung akan membayar porsi keuntungannya lebih besar sebagai dividen.

Tabel 1

Gambaran Dividend Payout Ratio (DPR) pada Perusahaan Pertambangan Batubara yang Terdaftar di Bursa Efek Indonesia Periode 2013-2015

\begin{tabular}{|c|c|c|c|c|}
\hline $\begin{array}{l}\text { Kode } \\
\text { Emiten }\end{array}$ & $\begin{array}{l}2013 \\
\text { (kali) }\end{array}$ & $\begin{array}{r}2014 \\
\text { (kali) }\end{array}$ & $\begin{array}{l}2015 \\
\text { (kali) }\end{array}$ & $\begin{array}{c}\text { Rata-rata } \\
\text { Per } \\
\text { Perusahaan } \\
\text { (Kali) }\end{array}$ \\
\hline ADRO & 0,33 & 0,42 & 0,49 & 0,41 \\
\hline ITMG & 0,43 & 0,79 & 0,93 & 0,71 \\
\hline MYOH & 0,33 & 0,37 & 0,32 & 0,34 \\
\hline PTBA & 0,56 & 0,36 & 0,31 & 0,41 \\
\hline TOBA & 0,35 & 0,35 & 0,10 & 0,27 \\
\hline $\begin{array}{c}\text { Rata-rata } \\
\text { Per } \\
\text { Tahun }\end{array}$ & 0,40 & 0,46 & 0,43 & 0,43 \\
\hline
\end{tabular}

Sumber : Perusahaan Pertambangan Batubara, (www.idx.com), Diolah

Dari Tabel 1 dapat dilihat bahwa nilai dividend payout ratio (DPR) pada setiap Perusahaan Pertambangan Batubara yang terdaftar di Bursa Efek Indonesia berfluktuasi dan cenderung meningkat. Pada tabel di atas menunjukkan bahwa kebijakan dividen suatu perusahaan setiap tahunnya berbeda-beda. $\mathrm{Hal}$ tersebut disebabkan oleh adanya faktor-faktor yang mempengaruhi kebijakan dividen tersebut seperti leverage dan profitabilitas.

\section{Rumusan Masalah}

a. Bagaimana gambaran profitabilitas, Bagaimana gambaran leverage, profitabilitas dan kebijakan dividen pada Perusahaan Pertambangan Batubara yang terdaftar di Bursa Efek Indonesia?

b. Bagaimana pengaruh leverage dan profitabilitas terhadap kebijakan dividen pada Perusahaan Pertambangan Batubara yang terdaftar di Bursa Efek Indonesia?

\section{Tujuan Penelitian}

a. Untuk mengetahui gambaran leverage, profitabilitas dan kebijakan dividen pada Perusahaan Pertambangan Batubara yang terdaftar di Bursa Efek Indonesia.

b. Untuk mengetahui pengaruh leverage dan profitabilitas terhadap kebijakan dividen pada Perusahaan Pertambangan Batubara yang terdaftar di Bursa Efek Indonesia.

\section{Metodologi Penelitian}

Desain penelitian yang digunakan dalam penelitian ini adalah penelitian kepustakaan (library research). Objek penelitian pada Perusahaan Pertambangan Batubara yang terdaftar di Bursa Efek Indonesia Periode 20132015. Penelitian ini dilakukan dengan menggunakan data skunder, untuk mendapatkan data informasi yang dibutuhkan dalam penelitian ini, maka dilakukan dengan cara mengakses dari situs http://www.idx.co.id

Teknik analisa data yang digunakan dalam penelitian ini adalah Uji Asumsi Klasik, Analisa Deskriptif Kualitatif, Analisa Deskriptif Kuantitatif

\section{B. LANDASAN TEORI}

\section{Laporan Keuangan}

Menurut Kasmir (2012:7), laporan keuangan laporan yang menunjukkan kondisi keuangan perusahaan pada saat ini atau dalam suatu periode tertentu. Maksud laporan keuangan yang menunjukkan kondisi perusahaan saat ini adalah merupakan kondisi terkini. Kondisi perusahaan terkini adalah keadaan keuangan perusahaan pada tanggal tertentu (untuk neraca) dan periode tertentu (untuk laporan laba rugi). Menurut Brigham dan Joel (2010:84), laporan keuangan adalah beberapa lembar kertas dengan angka-angka yang tertulis diatasnya, tetapi penting juga untuk memikirkan aset-aset nyata yang berada dibalik angka tersebut.

Menurut Kasmir (2012:11) terdapat 8 tujuan pembuatan atau penyusunan laporan keuangan, yaitu :

1) Memberikan informasi tentang jenis dan jumlah aktiva (harta) yang dimiliki perusahaan saat ini.

2) Memberikan informasi tentang jenis dan jumlah kewajiban dan modal yang dimiliki perusahaan pada saat ini.

3) Memberikan informasi tentang jenis dan jumlah pendapatan yang diperoleh pada suatu periode tertentu.

4) Memberikan informasi tentang jumlah biaya dan jenis biaya yang dikeluarkan perusahaan dalam suatu periode tertentu.

5) Memberikan informasi tentang perubahanperubahan yang terjadi terhadap aktiva, pasiva dan modal perusahaan.

6) Memberikan informasi tentang kinerja manajemen perusahaan dalam suatu periode. 
7) Memberikan informasi tentang catatancatatan atas laporan keuangan.

8) Informasi keuangan lainnya.

\section{Analisis Rasio Keuangan}

Menurut Horne dan John (2012:163), rasio keuangan merupakan indeks yang menghubungkan dua buah data keuangan dan diperoleh dengan membagi satu angka dengan angka lainnya.

Menurut Kasmir (2012:104), rasio keuangan merupakan kegiatan membandingkan angka-angka yang ada dalam laporan keuangan dengan cara membagi satu angka dengan angka yang lainnya. Perbandingan dapat dilakukan antara satu komponen dengan komponen dalam satu laporan keuangan atau antar komponen yang ada diantara laporan keuangan. Kemudian angka yang diperbandingkan dapat berupa angka-angka dalam satu periode maupun beberapa periode.

\section{Leverage}

Menurut Brigham dan Joel (2010:140), rasio leverage adalah rasio yang mengukur sampai sejauh mana perusahaan menggunakan pendanaan melalui utang. Faktor-faktor yang mempengaruhi leverage tersebut antara lain:

a. Risiko Usaha

Merupakan tingkat risiko usaha yang terkadung dalam operasi perusahaan jika perusahaan tidak menggunakan utang. Semakin besar risiko usaha perusahaan, semakin rendah rasio utang optimalnya.

b. Posisi Pajak Perusahaan

Salah satu utama digunakannya utang adalah karena bunga merupakan pengurang pajak, selanjutnya menurunkan biaya utang efektif. Akan tetapi, jika sebagian besar laba suatu perusahaan telah dilindungi dari pajak oleh perlindungan pajak yang berasal dari penyusutan, maka bunga atas utang yang saat ini belum dilunasi, atau kerugian pajak yang dibawa ke periode berikutnya akan menghasilkan tarif pajak yang rendah. Akibatnya, tambahan utang tidak akan memiliki kerugian yang sama jika dibandingkan dengan perusahaan yang memiliki tarif pajak efektif yang lebih tinggi.

\section{c. Fleksibilitas Keuangan}

Merupakan kemampuan untuk menghimpun modal dengan persyaratan yang wajar dalam kondisi yang buruk. Bendahara perusahaan tahu bahwa pasokan modal yang lancar dibutuhkan oleh operasi yang stabi,selanjutnya memiliki arti yang sangat penting bagi keberhasilan jangka panjang.

d. Konservatisme atau Keagresifan Manajerial Beberapa manajer lebih agresif dibandingkan manajer lain. Sehingga mereka lebih bersedia untuk menggunakan utang sebagai usaha untuk meningkatkan laba.

\section{Profitabilitas}

Menurut Sudana (2011:22), profitabilitas adalah rasio yang mengukur kemampuan perusahaan untuk menghasilkan laba dengan menggunakan sumber-sumber yang dimiliki perusahaan, seperti aktiva, modal atau penjualan perusahaan.

Faktor-faktor yang mempengaruhi profitabilitas antara lain :

a. Rasio Likuiditas

Likuiditas merupakan rasio yang digunakan untuk mengukur kemampuan perusahaan dalam memenuhi kewajiban jangka pendeknya, yang dihitung dengan membandingkan aset lancar dengan kewajiban lancar. Semakin tinggi tingkat likuiditas, maka semakin baiklah posisi perusahaan di mata kreditor.

b. Rasio Manajemen Aset

Manajemen aset yang digunakan untuk mengukur seberapa efektif perusahaan dalam mengelola asetnya. Efektivitas dalam pengelolaan aset akan membawa dampak positif bagi profitabilitas sebuah perusahaan.

\section{Kebijakan Deviden}

Menurut Astuti (2004:145), kebijakan dividen menyangkut keputusan untuk membagi laba atau menahannya guna diinvestasikan kembali di dalam perusahaan.

Menurut Atmaja (2003:291) faktor faktor yang menentukan kebijakan dividen adalah :

a. Perjanjian Hutang

b. Pembatasan dari saham preferen

c. Tersedianya kas

d. Pengendalian

e. Kebutuhan dana untuk investasi

f. Fluktuasi laba

\section{Pengaruh Leverage dan Profitabilitas terhadap Kebijakan Dividen}

Menurut Riyanto (2009:267), apabila perusahaan menetapkan bahwa pelunasan utangnya akan diambilkan dari laba ditahan, berarti perusahaan harus menahan sebagian besar pendapatannya untuk keperluan tersebut, yang berarti bahwa hanya sebagian kecil saja dari pendapatan atau earning yang dapat dibayarkan sebagai dividen. Dengan kata lain perusahaan harus menetapkan dividend payout ratio yang rendah. Berdasarkan pernyataan tersebut, semakin tinggi debt to equity ratio maka dividen yang akan dibagikan kepada pemegang saham pun rendah. Hal tersebut dikarenakan apabila utang perusahaan tinggi maka akan mengakibatkan beban utang yang tinggi sehingga perusahaan akan lebih mengutamakan pembayaran utang daripada 
pembagian dividen. Dengan demikian dapat dikatakan bahwa debt to equity ratio mempunyai pengaruh negatif terhadap dividend payout ratio.

Menurut Sartono (2010:73), besar kecilnya dividen sangat tergantung oleh besar kecilnya laba yang diperoleh dan proporsi laba yang akan dibagikan dalam bentuk dividen atau dividend payout ratio. Perusahaan yang cenderung menghasilkan laba yang tinggi maka cenderung akan membayar porsi keuntungannya lebih besar sebagai dividen. Sehingga semakin besar laba yang diperoleh, semakin besar pula kemampuan perusahaan untuk membayar dividen.

\section{PEMBAHASAN}

\section{Analisis}

a. Analisis Deskriptif Kualitatif

1) Gambaran Leverage pada Perusahaan Pertambangan Batubara yang Terdaftar di Bursa Efek Indonesia Periode 20132015.

Debt to Equity Ratio (DER) pada Perusahaan Pertambangan Batubara yang terdaftar di Bursa Efek Indonesia periode 20132015 pada Tabel 2 sebagai berikut :

\section{Tabel 2}

Debt to Equity Ratio (DER) pada Perusahaan

Pertambangan Batubara yang terdaftar di

Bursa Efek Indonesia Periode 2013-2015

\begin{tabular}{|c|c|c|c|c|c|}
\hline No & $\begin{array}{c}\text { Kode } \\
\text { Emiten }\end{array}$ & 2013 & 2014 & 2015 & $\begin{array}{c}\text { Rata-rata } \\
\text { Perusahaan }\end{array}$ \\
\hline 1 & ADRO & 1,11 & 0,97 & 0,78 & 0,95 \\
\hline 2 & ITMG & 0,44 & 0,45 & 0,41 & 0,44 \\
\hline 3 & $\mathrm{MYOH}$ & 1,32 & 1,02 & 0,73 & 1,02 \\
\hline 4 & PTBA & 0,55 & 0,71 & 0,82 & 0,69 \\
\hline 5 & TOBA & 1,39 & 1,11 & 0,82 & 1,11 \\
\hline & ata-rata & 0,96 & 0,85 & 0,71 & 0,84 \\
\hline \multicolumn{5}{|c|}{ Nilai Minimun DER } & 0,41 \\
\hline \multicolumn{5}{|c|}{ Nilai Maksimum DER } & 1,39 \\
\hline
\end{tabular}

\section{Sumber: Data Diolah}

Berdasarkan Tabel 2, dapat disajikan grafik perkembangan DER pada Perusahaan Pertambangan Batubara yang terdaftar di Bursa Efek Indonesia periode 2013-2015 sebagai berikut:

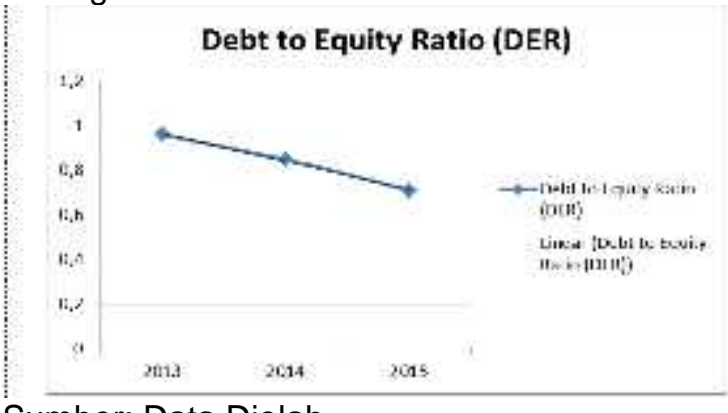

$$
\text { Sumber: Data Diolah }
$$

Grafik Perkembangan Debt to Equity Ratio

(DER) pada Perusahaan Pertambangan

Batubara yang terdaftar di Bursa Efek Indonesia periode 2013-2015
Berdasarkan gambar 1 di atas, diketahui bahwa Debt to Equity Ratio (DER) cenderung menurun. Hal ini disebabkan oleh total hutang perusahaan selama periode penelitian mengalami penurunan sedangkan total ekuitas cenderung mengalami peningkatan.

Berdasarkan tabel 2, nilai rata-rata Debt to Equity Ratio (DER) pada Perusahaan Pertambangan Batubara yang terdaftar di Bursa Efek Indonesia periode 2013-2015 adalah sebesar 0,84 . Terdapat 2 perusahaan yang berada di bawah rata-rata yaitu PT Indo Tambangraya Megah Tbk dan PT Tambang Batubara Bukit Asam Tbk. Sedangkan perusahaan yang berada di atas rata-rata yaitu PT Adaro Energy Tbk, PT Samindo Resources Tbk dan PT Toba Bara Sejahtera Tbk.

Nilai minimum Debt to Equity Ratio (DER) selama periode penelitian tahun 2013-2015 adalah sebesar 0,41 terdapat pada PT Indo Tambangraya Megah Tbk pada tahun 2015. Hal ini disebabkan total ekuitas perusahaan meningkat lebih besar daripada total utang perusahaan. Hal ini mengindikasikan bahwa perusahaan lebih memilih pendanaan melalui ekuitas dibandingkan dengan utang.

Nilai maksimum Debt to Equity Ratio (DER) selama periode penelitian tahun 20132015 adalah sebesar 1,39 terdapat pada PT Toba Bara Sejahtera Tbk pada tahun 2013. Hal ini disebabkan total utang perusahaan lebih besar daripada total ekuitas perusahaan.

2) Gambaran Profitabilitas pada Perusahaan Pertambangan Batubara yang Terdaftar di Bursa Efek Indonesia Periode 2013-2015

Return On Equity (ROE) pada Perusahaan Pertambangan Batubara yang terdaftar di Bursa Efek Indonesia periode 2013-2015 pada Tabel 3 sebagai berikut:

\section{Tabel 3}

Return On Equity (ROE) pada Perusahaan Pertambangan Batubara yang terdaftar di Bursa Efek Indonesia periode 2013-2015

\begin{tabular}{|c|c|c|c|c|c|}
\hline No & $\begin{array}{l}\text { Kode } \\
\text { Emiten }\end{array}$ & 2013 & 2014 & 2015 & $\begin{array}{c}\text { Rata-rata } \\
\text { Perusahaan }\end{array}$ \\
\hline 1 & ADRO & 0,07 & 0,06 & 0,05 & 0,06 \\
\hline 2 & ITMG & 0,24 & 0,22 & 0,08 & 0,18 \\
\hline 3 & $\mathrm{MYOH}$ & 0,22 & 0,27 & 0,26 & 0,25 \\
\hline 4 & PTBA & 0,25 & 0,23 & 0,22 & 0,23 \\
\hline 5 & TOBA & 0,27 & 0,25 & 0,17 & 0,23 \\
\hline & ta-rata & 0,21 & 0,21 & 0,15 & 0,19 \\
\hline \multicolumn{5}{|c|}{ Nilai Minimun ROE } & 0,05 \\
\hline \multicolumn{5}{|c|}{ Nilai Maksimum ROE } & 0,27 \\
\hline
\end{tabular}

Sumber: Data Diolah

Berdasarkan Tabel 3 dapat disajikan grafik perkembangan ROE sebagai berikut: 


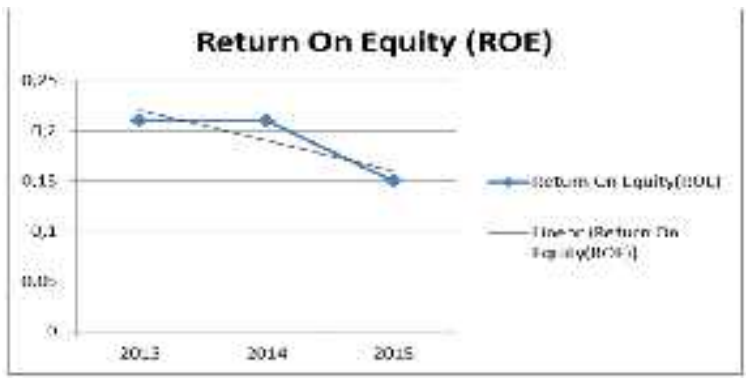

Sumber: Data Diolah

Gambar 2

Grafik Perkembangan Return On Equity

(ROE) pada Perusahaan Pertambangan

Batubara yang terdaftar di Bursa Efek Indonesia Periode 2013-2015

Berdasarkan gambar 2 di atas, diketahui bahwa Return On Equity (ROE) cenderung menurun. Hal ini disebabkan oleh laba perusahaan selama periode penelitian cenderung mengalami penurunan sedangkan ekuitas cenderung mengalami peningkatan.

Berdasarkan tabel 3, nilai rata-rata Return On Equity (ROE) pada Perusahaan Pertambangan Batubara yang terdaftar di Bursa Efek Indonesia periode 2013-2015 adalah sebesar 0,19 . Terdapat 2 perusahaan yang berada di bawah rata-rata yaitu PT Adaro Energy Tbk dan PT Indo Tambangraya Megah Tbk. Sedangkan perusahaan yang berada $d i$ atas rata-rata yaitu, PT Samindo Resources Tbk, PT Tambang Batubara Bukit Asam Tbk dan PT Toba Bara Sejahtera Tbk.

Nilai minimum Return On Equity (ROE) selama periode penelitian tahun 2013-2015 adalah sebesar 0,05 terdapat pada PT Adaro Energy Tbk pada tahun 2015. Hal ini disebabkan oleh rendahnya perolehan laba setelah pajak dan meningkatnya total ekuitas dari tahun sebelumnya.

Nilai maksimum Return On Equity (ROE) selama periode penelitian tahun 2013-2015 adalah sebesar 0,27 terdapat pada PT Toba Bara Sejahtera Tbk pada tahun 2013 dan PT Samindo Resources Tbk pada tahun 2014. Hal ini disebabkan oleh peningkatan total ekuitas lebih besar dibandingkan peningkatan laba setelah pajak.

3) Gambaran Kebijakan Dividen pada pada Perusahaan Pertambangan Batubara yang Terdaftar di Bursa Efek Indonesia Periode 2013-2015

Dividend Payout Ratio (DPR) pada pada Perusahaan Pertambangan Batubara yang terdaftar di Bursa Efek Indonesia periode 20132015 pada Tabel 4 sebagai berikut :
Tabel 4

Dividend Payout Ratio (DPR) pada

Perusahaan Pertambangan Batubara yang terdaftar di Bursa Efek Indonesia Periode

2013-2015

\begin{tabular}{|c|c|c|c|c|c|}
\hline No & $\begin{array}{l}\text { Kode } \\
\text { Emiten }\end{array}$ & 2013 & 2014 & 2015 & $\begin{array}{c}\text { Rata-rata } \\
\text { Perusahaan }\end{array}$ \\
\hline 1 & ADRO & 0,33 & 0,42 & 0,49 & 0,41 \\
\hline 2 & ITMG & 0,43 & 0,79 & 0,93 & 0,71 \\
\hline 3 & $\mathrm{MYOH}$ & 0,33 & 0,37 & 0,32 & 0,34 \\
\hline 4 & PTBA & 0,56 & 0,36 & 0,31 & 0,41 \\
\hline 5 & TOBA & 0,35 & 0,35 & 0,10 & 0,27 \\
\hline \multicolumn{2}{|c|}{ Rata-rata } & 0,40 & 0,46 & 0,43 & 0,43 \\
\hline \multicolumn{5}{|c|}{ Nilai Minimun DPR } & 0,10 \\
\hline \multicolumn{5}{|c|}{ Nilai Maksimum DPR } & 0,93 \\
\hline
\end{tabular}

\section{Sumber : Data Diolah}

Berdasarkan Tabel 4 di atas, perkembangan DPR pada Perusahaan Pertambangan Batubara yang terdaftar di Bursa Efek Indonesia periode 2013-2015 sebagai berikut:

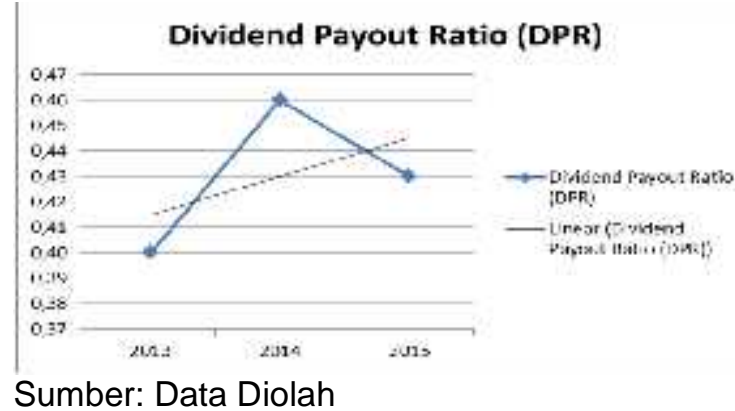

Gambar 3

Grafik Perkembangan Dividend Payout Ratio (DPR) pada Perusahaan Pertambangan Batubara yang terdaftar di Bursa Efek Indonesia periode 2013-2015

Berdasarkan gambar 6 di atas, diketahui bahwa Dividend Payout Ratio (DPR) selama periode penelitian berfluktuasi dan cenderung mengalami peningkatan. Hal ini disebabkan oleh laba per saham (EPS) selama periode penelitian cenderung mengalami penurunan.

Berdasarkan tabel 4, nilai rata-rata Dividend Payout Ratio (DPR) pada Perusahaan Pertambangan Batubara yang terdaftar di Bursa Efek Indonesia periode 2013-2015 adalah sebesar 0,43. Terdapat 4 perusahaan yang berada di bawah rata-rata yaitu PT Adaro Energy Tbk, PT Samindo Resources Tbk, PT Tambang Batubara Bukit Asam Tbk dan PT Toba Bara Sejahtera Tbk. Sedangkan perusahaan yang berada di atas rata-rata yaitu PT Indo Tambangraya Megah Tbk.

Nilai minimum Dividend Payout Ratio (DPR) selama periode penelitian tahun 20132015 adalah sebesar 0,10 terdapat pada PT Toba Bara Sejahtera Tbk pada tahun 2015. Hal ini disebabkan karena menurunnya nilai Dividend Per Share (DPS) secara drastis tidak sebanding dengan menurunnya nilai Earning Per Share (EPS).

Nilai maksimum Dividend Per Share (DPS) selama periode penelitian tahun 2013-2015 
adalah sebesar 0,93 terdapat pada PT Indo Tambangraya Megah pada tahun 2015. Hal ini disebabkan oleh penurunan Earning Per Share (EPS) lebih besar dibandingkan penurunan Dividend Per Share (DPS).

\section{b. Analisis Deskriptif Kuantitatif}

1) Analisis Regresi Linier Berganda

Analisis regresi linier berganda pada penelitian ini menggunakan SPSS versi 21 . dengan hasil sebagai berikut:

Tabel 5

Tabel Analisis Regresi Linier Berganda Coefficients ${ }^{a}$

\begin{tabular}{|c|c|c|c|}
\hline \multirow[t]{2}{*}{ Model } & \multicolumn{2}{|c|}{$\begin{array}{c}\text { Unstandardized } \\
\text { Coefficients }\end{array}$} & $\begin{array}{c}\text { Standardized } \\
\text { Coefficients }\end{array}$ \\
\hline & $B$ & Std. Error & Beta \\
\hline (Constant) & ,836 & ,163 & \\
\hline 1 DER &,- 375 & , 149 &,- 572 \\
\hline ROE &,- 479 &, 560 &,- 194 \\
\hline
\end{tabular}

Sumber : Hasil Pengelolahan Data (SPSS 21)

Berdasarkan Tabel 5, model persamaan regresi yang diperoleh adalah sebagai berikut:

\section{$\hat{\mathbf{Y}}=\mathbf{0 , 8 3 6}-0,375 \mathrm{X}_{1}-\mathbf{0 , 4 7 9 \mathrm { X } _ { 2 }}$}

Berdasarkan model persamaan regresi berganda tersebut, dapat diartikan bahwa leverage dan profitablitas berpengaruh negatif terhadap kebijakan dividen pada Perusahaan Pertambangan Batubara yang terdaftar di Bursa Efek Indonesia periode 2013-2015.

\section{2) Koefesien Korelasi dan Koefisien Determinasi}

Berikut hasil pengelolahan data yang menunjukkan koefesien dan determinasi:

Tabel 6

Hasil pengujian Koefisien Korelasi dan Determinasi

Model Summary

\begin{tabular}{|l|c|r|r|r|r|}
\hline Model & $\mathrm{R}$ & $\begin{array}{c}\mathrm{R} \\
\text { Square }\end{array}$ & $\begin{array}{c}\text { Adjusted } \\
\text { R Square }\end{array}$ & $\begin{array}{c}\text { Std. Error } \\
\text { of the } \\
\text { Estimate }\end{array}$ & $\begin{array}{r}\text { Durbin- } \\
\text { Watson }\end{array}$ \\
\hline 1 &, $621^{\mathrm{a}}$ &, 386 &, 283 &, 17187 & 1,602 \\
\hline
\end{tabular}

. Predictors: (Constant), ROE, DER

b. Dependent Variable: DPR

Sumber : Hasil Pengelolahan Data (SPSS 21.)

Berdasarkan Tabel 6 nilai $r$ adalah 0,621 yang artinya bahwa terdapat hubungan yang kuat antara variabel leverage dan profitabilitas terhadap kebijakan dividen. Sementara koefisien determinasi ( $R$ Square) adalah 0,386 yang berarti bahwa variabel leverage dengan proksi Debt to Equity Ratio dan profitabilitas dengan proksi Return On Equity berpengaruh $38,6 \%$ terhadap kebijakan dividen dengan proksi Dividend Payout Ratio (DPR), sedangkan sisanya $61,4 \%$ dipengaruhi oleh faktor lainnya yang tidak dijelaskan dalam penelitian ini seperti Debt to Asset (DAR), Return On Asset
(ROA), Current Ratio (CR) dan faktor eksternal lainnya yang tidak dibahas dalam penelitian ini.

\section{3) Uji Hipotesis}

Hipotesis yang diuji dalam penelitian ini adalah uji simultan (Uji F) dan uji parsial (Uji t), sebagai berikut :

\section{a) Uji Simultan (Uji F)}

Uji $F$ menunjukkan apakah semua variabel idependen yang dimasukkan dalam model regresi mempunyai pengaruh secara bersama-sama terhadap variabel dependen. Uji $F$ berhubungan erat dengan nilai koefesien determinasi $(R)$, maka pada saat melakukkan uji $F$, sesungguhnya menguji signifikansi koefesiensi determinasi $(R)$.

Hasil perkiraan dari nilai $F_{\text {hitung }}$ dalam penelitian ini disajikan pada Tabel 7 .

\begin{tabular}{|ll|l|l|}
\multicolumn{3}{|c|}{$\begin{array}{c}\text { Tabel 7 } \\
\text { Hasil Uji F } \\
\text { ANOVA }^{\mathrm{a}}\end{array}$} \\
\hline Model & \multicolumn{1}{|c|}{ F } & Sig. \\
\hline 1 & $\begin{array}{l}\text { Regression } \\
\text { Residual } \\
\text { Total }\end{array}$ & 3,765 &, $054^{\mathrm{b}}$ \\
\hline
\end{tabular}

a. Dependent Variable: DPR

b. Predictors: (Constant), ROE, DER

Sumber : Hasil Pengelolahan Data (SPSS 21)

Berdasarkan Tabel 20, hasil uji $F$ yang ditampilkan menunjukkan bahwa nilai $F_{\text {hitung }}$ adalah 3,765 dengan tingkat signifikansi 0,054 yang lebih besar dari 0,05 atau dapat dikatakan $0,054>0,05$ maka $\mathrm{H}_{0}$ diterima dan nilai df1 = $(3-1)=2$ dan df2 $=(15-2-1)=12$ di peroleh nilai $F_{\text {tabel }}$ sebesar 3,89. Karena $F_{\text {hitung }}<F_{\text {tabel }}$ maka $\mathrm{H}_{0}$ diterima, yang berarti bahwa leverage dan profitabilitas berpengaruh tidak signifikan terhadap kebijakan dividen pada Perusahaan Pertambangan Batubara yang terdaftar di Bursa Efek Indonesia.

b) Uji Parsial (Uji t).

Hasil uji t dalam penelitian ini dapat dilihat pada Tabel 8

Tabel 8

\section{Hasil Uji t}

Coefficients $^{\mathrm{a}}$

\begin{tabular}{|l|r|r|r|}
\hline \multirow{2}{*}{ Model } & \multicolumn{1}{|c|}{$\begin{array}{c}\text { Standardized } \\
\text { Coefficients }\end{array}$} & \multicolumn{1}{c|}{ Sig. } & \\
\cline { 2 - 3 } & \multicolumn{1}{|c|}{ Beta } & & \\
\hline (Constant) &,- 572 & 5,127 &, 000 \\
1 DER & $-2,516$ &, 027 \\
ROE &,- 194 &,- 856 &, 409 \\
\hline
\end{tabular}

Sumber: Hasil Pengolahan Data (SPSS 21)

Berdasarkan Tabel 8 di atas, untuk variabel leverage, $t_{\text {hitung }}>t_{\text {tabel }}(2,516>2,17881)$ atau Sig. < alpha $(0,027<0,05)$ maka $\mathrm{H}_{0}$ ditolak, artinya leverage berpengaruh signifikan 
terhadap kebijakan dividen pada Perusahaan Pertambangan Batubara yang terdaftar di Bursa Efek Indonesia.

Untuk profitabilitas, $t_{\text {hitung }}<t_{\text {tabel }}(0,856<$ $2,17881)$ atau Sig. $>$ alpha $(0,409>0,05)$ maka $\mathrm{H}_{0}$ diterima, artinya profitabilitas berpengaruh tidak signifikan terhadap kebijakan dividen pada Perusahaan Pertambangan Batubara yang terdaftar di Bursa Efek Indonesia.

\section{Evaluasi}

a. Evaluasi Leverage pada Perusahaan Pertambangan Batubara yang terdaftar di Bursa Efek Indonesia periode 2013-2015

Debt to Equity Ratio (DER) cenderung menurun. Hal ini disebabkan oleh total hutang perusahaan selama periode penelitian mengalami penurunan sedangkan total ekuitas cenderung mengalami peningkatan. Hal ini mengindikasikan bahwa perusahaan lebih memilih pendanaan melalui ekuitas dibandingkan dengan menggunakan utang. Rendahnya rasio hutang atau Debt to Equity Ratio (DER) lebih disukai oleh kreditor, karena semakin rendah rasio hutang maka semakin besar perlindungan terhadap kerugian kreditor apabila perusahaan dilikuidasi.

sebaiknya perusahaan menekan bebanbeban operasional dan mengendalikan hutang untuk menambah pendanaan sesuai dengan kemampuan perusahaan agar dapat menunjang aktivitas perusahaan. Apabila rasio hutang dapat dimaksimalkan maka perusahaan akan memperoleh laba yang besar

\section{b. Evaluasi Profitabilitas pada Perusahaan} Pertambangan Batubara yang terdaftar di Bursa Efek Indonesia periode 2013-2015

Return On Equity (ROE) pada Perusahaan Pertambangan Batubara yang terdaftar di Bursa Efek Indonesia periode 2013-2015 cenderung menurun. Hal ini disebabkan oleh laba perusahaan selama periode penelitian cenderung mengalami penurunan sedangkan ekuitas cenderung mengalami peningkatan.

Untuk itu sebaiknya perusahaan diharapkan mampu meningkatkan kinerjanya sehingga dapat meningkatkan persentase laba setiap tahunnya dengan cara mengefisiensikan biaya dan meningkatkan produktifitas penjualan. Penjualan yang meningkat dapat meningkatkan laba, sehingga diharapkan dapat meningkatkan profitabilitas. Perusahaan yang menghasilkan laba yang tinggi belum tentu membagikan dividen dalam jumlah yang besar pula, karena perusahaan cenderung menahan sebagian labanya untuk di investasikan kembali dengan tujuan memperoleh laba yang lebih besar di masa mendatang. Perusahaan juga dapat menggunakan saldo laba ditahan untuk membagikan dividen kepada pemegang saham apabila laba perusahaan mengalami penurunan.

\section{c. Evaluasi Kebijakan Dividen pada Perusahaan Pertambangan Batubara yang terdaftar di Bursa Efek Indonesia periode 2013-2015 \\ Dividend Payout Ratio (DPR) pada} Perusahaan Pertambangan Batubara yang terdaftar di Bursa Efek Indonesia periode 20132015 berfluktuasi dan cenderung mengalami peningkatan, Hal ini disebabkan oleh laba per saham (EPS) selama periode penelitian cenderung mengalami penurunan.

Untuk itu sebaiknya perusahaan menambah proporsi dividen yang akan dibagikan kepada pemegang saham sampai tingkat kemampuan perusahaan. Perusahaan juga dapat menerbitkan saham baru guna menurunkan nilai laba per saham sehingga perusahaan tetap dapat mempertahankan ataupun meningkatkan rasio Dividend Payout Ratio (DPR), sehingga dapat menambah minat investor untuk berinvestasi.

d. Evaluasi Leverage dan Profitabilitas

Terhadap Kebijakan Dividen pada

Perusahaan Pertambangan Batubara

yang terdaftar di Bursa Efek Indonesia

Berdasarkan hasil regresi linier berganda, diketahui bahwa leverage dan profitabilitas memiliki pengaruh negatif terhadap kebijakan dividen dengan hasil $\hat{\mathbf{Y}}=\mathbf{0 , 8 3 6}-\mathbf{0 , 3 7 5 \mathrm { X } _ { 1 } -}$ $\mathbf{0}, \mathbf{4 7 9} \mathbf{X}_{2}$. Persamaan tersebut menunjukkan bahwa besarnya pengaruh leverage yang diukur dengan debt to equity ratio (DER) terhadap kebijakan dividen yang diukur dengan dividend payout ratio (DPR) adalah sebesar 0,375 , yang artinya bahwa setiap leverage mengalami kenaikan 1 satuan, maka akan menyebabkan penurunan terhadap kebijakan dividen sebesar 0,375 satuan. Angka ini menunjukan bahwa pengaruh leverage terhadap kebijakan dividen adalah negatif.

Sementara besarnya pengaruh profitabilitas yang diproksikan dengan return on equity (ROE) terhadap kebijakan dividen adalah sebesar $-0,479$, yang artinya bahwa setiap profitabilitas mengalami kenaikan 1 satuan, maka akan menyebabkan penurunan terhadap kebijakan dividen sebesar 0,479. Hasil penelitian ini menunjukkan bahwa Return on equity (ROE) berpengaruh negatif terhadap dividend payout ratio (DPR), perusahaan dengan laba yang rendah belum tentu tidak mampu membayarkan dividen karena ada kecenderungan kebijakan dari perusahaan dan RUPS dalam pembagian dividen yang stabil bagi pemegang saham, artinya meskipun perusahaan mengalami penurunan laba maka perusahaan tetap membagikan dividen kepada pemegang saham setiap tahunnya. Hal tersebut dilakukan untuk dapat menarik minat para investor untuk berinvestasi.

Dari pengujian koefisien kolerasi dan determinasi diketahui bahwa nilai $\mathrm{R}$ adalah 
sebesar 0,621, yang artinya terdapat korelasi atau hubungan yang kuat antara variabel independen (leverage dan profitabilitas) terhadap variabel dependen (kebijakan dividen). Sementara koefisien determinasi ( $\mathrm{R}$ Square) adalah sebesar 0,386 . Angka ini mempunyai arti bahwa leverage yang diproksikan dengan debt to equity ratio (DER) dan profitabilitas yang diproksikan dengan return on equity (ROE) mampu menjelaskan variasi kebijakan dividen yang diproksikan dengan dividend payout ratio (DPR) pada Perusahaan Pertambangan Batubara yang terdaftar di Bursa Efek Indonesia Periode 2013 sampai dengan 2015 sebesar $38,6 \%$ dan sisanya sebesar $61,4 \%$ dijelaskan oleh variabel lain yang tidak dijelaskan dalam penelitian ini, seperti Debt to Asset (DAR), Return On Asset (ROA), Current Ratio (CR) dan variabel lainnya.

Dari hasil uji $F$, diperoleh nilai $F_{\text {hitung }}$ adalah 3,765 dengan tingkat signifikansi 0,054 yang lebih besar dari 0,05 atau dapat dikatakan $0,054>0,05$ maka $\mathrm{H}_{0}$ diterima dan nilai df $1=$ $(3-1)=2$ dan df2 $=(15-2-1)=12$ di peroleh nilai $F_{\text {tabel }}$ sebesar 3,89. Karena $F_{\text {hitung }}<F_{\text {tabel }}$ maka $\mathrm{H}_{0}$ diterima, yang berarti bahwa leverage dan profitabilitas berpengaruh tidak signifikan terhadap kebijakan dividen pada Perusahaan Pertambangan Batubara yang terdaftar di Bursa Efek Indonesia.

Dari hasil uji $t$, diperoleh nilai $t_{\text {hitung }}$ pada variabel $\mathrm{X}_{1}$ (debt to equity ratio) sebesar 2,516 . Dengan df sebesar alpha dibagi $2(0,05: 2=$ $0,025)$ dan $n-k-1=15-2-1=12$ dimana $k$ adalah variabel bebas dan $\mathrm{n}$ adalah jumlah data didapatkan nilai $t_{\text {tabel }}$ sebesar 2,17881, maka $t_{\text {hitung }}>t_{\text {tabel }}(2,516>2,17881)$ atau dengan taraf signifikansi $0,027<0,05$, maka $\mathrm{H}_{0}$ ditolak, artinya leverage berpengaruh signifikan terhadap kebijakan dividen pada Perusahaan Pertambangan Batubara yang terdaftar di Bursa Efek Indonesia. Untuk variabel $\mathrm{X}_{2}$ (return on equity) diperoleh nilai $t_{\text {hitung }}<t_{\text {tabel }}(0,856<$ $2,17881)$ atau dengan taraf signifikansi $0,409>$ 0,05 , maka $H_{0}$ diterima, artinya profitabilitas berpengaruh tidak signifikan terhadap kebijakan dividen pada Perusahaan Pertambangan Batubara yang terdaftar di Bursa Efek Indonesia.

\section{KESIMPULAN DAN SARAN}

1. Kesimpulan

a. Nilai rata-rata Leverage yang dihitung dengan debt to equity ratio (DER) pada Perusahaan Pertambangan Batubara yang terdaftar di Bursa Efek Indonesia Periode 2013-2015 adalah sebesar 0,84. Terdapat 2 perusahaan yang berada di bawah rata-rata yaitu PT Indo Tambangraya Megah Tbk dan PT Tambang Batubara Bukit Asam Tbk. Sedangkan perusahaan yang berada di atas rata-rata yaitu PT Adaro Energy Tbk, PT
Samindo Resources Tbk dan PT Toba Bara Sejahtera Tbk.

b. Nilai rata-rata profitabilitas yang dihitung dengan return on equity (ROE) pada Perusahaan Pertambangan Batubara yang terdaftar di Bursa Efek Indonesia Periode 2013-2015 adalah sebesar 0,19. Terdapat 2 perusahaan yang berada di bawah rata-rata yaitu PT Adaro Energy Tbk dan PT Indo Tambangraya Megah Tbk. Sedangkan perusahaan yang berada di atas rata-rata yaitu, PT Samindo Resources Tbk, PT Tambang Batubara Bukit Asam Tbk dan PT Toba Bara Sejahtera Tbk.

c. Nilai rata-rata kebijakan dividen yang dihitung dengan dividend payout ratio (DPR) pada Perusahaan Pertambangan Batubara yang terdaftar di Bursa Efek Indonesia Periode 2013-2015 adalah sebesar 0,43. Terdapat 4 perusahaan yang berada di bawah rata-rata yaitu PT Adaro Energy Tbk, PT Samindo Resources Tbk, PT Tambang Batubara Bukit Asam Tbk dan PT Toba Bara Sejahtera Tbk. Sedangkan perusahaan yang berada di atas rata-rata yaitu PT Indo Tambangraya Megah Tbk.

d. Dari hasil pengujian regresi linear berganda diperoleh persamaan regresi $\hat{Y}=\mathbf{0 , 8 3 6}$ $\mathbf{0}, \mathbf{3 7 5} \mathrm{X}_{\mathbf{1}}-\mathbf{0}, \mathbf{4 7 9} \mathrm{X}_{\mathbf{2}}$. Artinya leverage dan profitablitas berpengaruh negatif terhadap kebijakan dividen pada Perusahaan Pertambangan Batubara yang terdaftar di Bursa Efek Indonesia periode 2013-2015.

e. Dari uji koefisien korelasi dan determinasi diperoleh nilai korelasi sebesar 0,621 yang artinya bahwa terdapat hubungan yang kuat antara variabel independen (leverage dan profitabilitas) terhadap variabel dependen (kebijakan dividen). Sementara untuk koefisien determinasi ( $R$ square) diperoleh nilai sebesar 0,386 , artinya variabel leverage yang diproksikan dengan debt to equity ratio dan profitabilitas yang diproksikan dengan return on equity berpengaruh $38,6 \%$ terhadap kebijakan dividen yang diproksikan dengan dividend payout ratio (DPR), sedangkan sisanya $61,4 \%$ dipengaruhi oleh faktor lainnya yang tidak dijelaskan dalam penelitian ini seperti Debt to Asset (DAR), Return On Asset (ROA), Current Ratio (CR) dan faktor eksternal lainnya yang tidak dibahas dalam penelitian ini.

f. Hasil uji $F$, diperoleh nilai $F_{\text {hitung }}<F_{\text {tabel }}$ atau $3,765<3,89$ atau Sig. $<$ alpha $(0,054>0,05)$ maka $\mathrm{H}_{0}$ diterima, yang berarti bahwa leverage dan profitabilitas berpengaruh tidak signifikan terhadap kebijakan dividen pada Perusahaan Pertambangan Batubara yang terdaftar di Bursa Efek Indonesia.

g. Hasil uji $t$, pada variabel $X_{1}$ (leverage) diperoleh nilai $t_{\text {hitung }}>t_{\text {tabel }}(2,516>2,17881)$ atau Sig. < alpha $(0,027<0,05)$ maka $\mathrm{H}_{0}$ ditolak, artinya leverage berpengaruh 
signifikan terhadap kebijakan dividen pada Perusahaan Pertambangan Batubara yang terdaftar di Bursa Efek Indonesia. Pada variabel $\mathrm{X}_{2}$ (return on equity) diperoleh nilai $t_{\text {titung }}<t_{\text {tabel }}(0,856<2,17881)$ atau Sig. $>$ alpha $(0,409>0,05)$ maka $\mathrm{H}_{0}$ diterima, artinya profitabilitas berpengaruh tidak signifikan terhadap kebijakan dividen pada Perusahaan Pertambangan Batubara yang terdaftar di Bursa Efek Indonesia.

\section{Saran}

a. Perusahaan sebaiknya menekan bebanbeban operasional dan mengendalikan hutang untuk menambah pendanaan sesuai dengan kemampuan perusahaan agar dapat menunjang aktivitas perusahaan. Apabila rasio hutang dapat dimaksimalkan maka perusahaan akan memperoleh laba yang besar.

b. Perusahaan sebaiknya mampu meningkatkan kinerjanya sehingga dapat meningkatkan persentase laba setiap tahunnya dengan cara mengefisiensikan biaya dan meningkatkan produktifitas penjualan. Penjualan yang meningkat dapat meningkatkan laba, sehingga diharapkan dapat meningkatkan profitabilitas.

c. Perusahaan sebaiknya menambah proporsi dividen yang akan dibagikan kepada pemegang saham sampai tingkat kemampuan perusahaan. Perusahaan juga dapat menerbitkan saham baru guna menurunkan nilai laba per saham sehingga perusahaan tetap dapat mempertahankan ataupun meningkatkan Dividend Payout Ratio (DPR), sehingga dapat menambah minat investor untuk berinvestasi.

\section{E. DAFTAR PUSTAKA}

Astuti, Dewi. 2004. Manajemen Keuangan Perusahaan. Jakarta: Ghalia Indonesia

Atmaja, Lukas Setia. 2003. Manajemen Keuangan. Edisi 2. Yogyakarta: Penerbit Andi.

Brigham, Eugene F dan Joel F, Houston. 2010. Dasar-dasar Manajemen Keuangan: Essentials of Financial Management. Edisi Kesebelas. Jakarta: Salemba Empat.

Horne, James C. Van dan John M. Wachowicz. 2012. Prinsip-prinsip Manajemen Keuangan. Edisi ketiga belas. Buku 1. Jakarta: Salemba Empat.

Kasmir. 2012. Analisis laporan Keuangan. Jakarta: Rajawali Pers.

http://www.ix.co.id/id-

$\mathrm{id} /$ beranda/perusahaantercatat/laporanke uangandan tahunan.aspx. diakses tahun 2017

Riyanto, Bambang. 2009. Dasar-dasar Pembelanjaan Perusahaan. Edisi
Keempat, Cetakan VI. Yogyakarta: BPFE UGM.

Sartono, Agus. 2010. Manajemen Keuangan Teori dan Aplikasi, Edisi Empat. Yogyakarta: BPFE Yogyakarta.

Sudana, I Made. 2011. Manajemen Keuangan Perusahaan Teori dan Praktek. Jakarta: Erlangga. 